\title{
EIGHT MONTHS' EXPERIENCE OF FOOD INSPECTION AT THE PORT OF MANCHESTER.*
}

BY W. F. DEARDEN, M.R.C.S., L.R.C.P., D.P.H., Medical Officer of Health of the Port of Manchester.

\begin{abstract}
A $\mathrm{T}$ the last meeting of the Association I enjoyed the privilege, A in conjunction with my colleague, Mr. Arthur Holmes, of giving an account of the reasons which induced the Port Authority of Manchester to apply for powers to inspect food imports. The Order which was obtained has now been in operation for a little over eight months; and I have thought this a favourable opportunity to give you some account of the work we have been able to accomplish, along with a few comments on results obtained, and difficulties which have arisen in the course of our operations.

Inspections were commenced by the chief food inspector on the 5th March last; and on the 2nd April another inspector was able to start duty. Both inspectors possess Meat Inspectors' Certificates, as well as their qualifications as Sanitary Inspectors. The chief inspector has had previous experience in inspecting imported foodstuffs, and the junior has had charge of extensive abattoirs in a large Lancashire town. Both have served their apprenticeship, and been in actual business, as butchers. The duties of the former are mostly concerned with the examination of general food imports, whilst those of the latter are principally concerned with the inspection of meat at the Foreign Animals' Wharf, though either assists the other as occasion requires.
\end{abstract}

The seizures for the eight months, made up to October 27 th, show a gross amount of 197 tons $10 \mathrm{cwt} .1 \mathrm{qr} .20 \mathrm{lbs}$, this eonsisting of 189 tons 4 cwt. 3 qrs. 10 lbs. of various foods from the different dock quays, and 8 tons 5 cwt. 2 qrs. 10 lbs. of diseased material from the Foreign Animals' Wharf. The appended tables show the different seizures in detail, but it may be noted that the principal articles dealt with, in connection with the former, have been grain, fruit, and canned goods. In connection with the latter we have seized several carcases and parts of beef, and a large number of immature calves, also numbers of every type of organ.

As regards grain, I found that it was customary among importers to dispose of their damaged goods to dealers in this elass of unsound material, who again got rid of it in directions which could not be

* Read at the Annual Meeting of Association of Port Sanitary Authorities, November 14 th, 1907. 
very well ascertained. Although grain is, primâ facie, intended for human consumption, it has also, even when sound, a large market for other purposes; but when obviously unsound, I regard it as essential that the inspecting authority should know absolutely what is to become of it if it is released for other purposes than human food. When, therefore, my inspectors seize any parcels of this kind,

SEIZED AT THE DOCKS.

5th March to 27th October, 1907.

\begin{tabular}{|c|c|c|c|c|c|c|c|}
\hline \multicolumn{4}{|c|}{ ARTICLES. } & Tons. & Owt. & Qrs. & Lbs. \\
\hline Wheat & $\ldots$ & $\ldots$ & $\ldots$ & $89^{\circ}$ & 7 & 2 & 11 \\
\hline Corn & $\ldots$ & $\ldots$ & $\ldots$ & 7 & 8 & 3 & 25 \\
\hline Barley & $\ldots$ & $\ldots$ & $\ldots$ & 1 & 15 & 1 & 0 \\
\hline Oranges & case & $\ldots$ & $\ldots$ & 1 & 5 & 1 & 0 \\
\hline Onions & cases) & $\cdots$ & $\ldots$ & 3 & 18 & 0 & 0 \\
\hline Lemons & cases) & $\ldots$ & $\ldots$ & - & - & 4 & 2 \\
\hline Melons & case & $\ldots$ & $\ldots$ & 48 & 2 & 2 & 0 \\
\hline Apples & oarrel & $\ldots$ & $\cdots$ & - & 10 & 0 & 0 \\
\hline Pears ( & xes) & $\ldots$ & $\cdots$ & - & 1 & 1 & 0 \\
\hline Cocoant & $7 \frac{1}{2} \mathrm{ba}$ & $\ldots$ & $\ldots$ & - & 9 & 2 & 0 \\
\hline Apricot & $p(43$ & & $\ldots$ & 2 & 2 & 3 & 5 \\
\hline Black $\mathrm{C}$ & $\ln t$ & & $\ldots$ & 3 & 10 & 0 & 11 \\
\hline 'Tomato & ree $(2$ & ins) & $\ldots$ & 1 & 12 & 1 & 8 \\
\hline Tomato & 37 tin & $\ldots$ & $\ldots$ & - & 2 & 1 & 4 \\
\hline Liquid & $s(6 \mathrm{ti}$ & & $\ldots$ & - & 1 & 3 & 22 \\
\hline Conden & Milk & tins) & $\ldots$ & - & 6 & 0 & 23 \\
\hline Tinned & $\operatorname{mon}($ & & $\ldots$ & - & - & - & 6 \\
\hline " & $f(36)$ & & $\ldots$ & 1 & 0 & 0 & 10 \\
\hline & gue ( & tins) & $\ldots$ & $\overline{-}$ & 6 & 1 & 27 \\
\hline Potatoe & $\ldots$ & $\ldots$ & $\ldots$ & 11 & 19 & 1 & 12 \\
\hline Glucose & ba.gs) & $\ldots$ & $\ldots$ & - & 8 & 0 & 0 \\
\hline Lard & & $\ldots$ & $\ldots$ & - & 3 & 1 & 24 \\
\hline Lemon & $1(23$ & & $\ldots$ & 7 & 15 & 1 & $\theta$ \\
\hline Corn $\mathrm{Fl}$ & (115 & )... & $\ldots$ & 6 & 16 & 3 & 24 \\
\hline Bacon & $\ldots$ & $\ldots$ & $\ldots$ & 一 & 一 & - & 6 \\
\hline \multirow[t]{2}{*}{ Hams } & $\ldots$ & $\cdots$ & ... & - & - & - & 14 \\
\hline & & & Total & 189 & 4 & 3 & 10 \\
\hline
\end{tabular}

and the importer claims that such are not intended for human food, none of them are allowed to leave our jurisdiction without my being supplied with the name and address of the actual user; the purpose for which it is to be used having also to be proved to my satisfaction. If these conditions are not fulfilled within a reasonable length of time, I obtain a magistrate's order for the destruction of the material. At first these conditions were regarded as very arbitrary by the parties interested; but I am pleased to say that all appear to have been brought very nicely into line, so that we now have very little trouble in getting our requirements complied with. We are thus brought into touch with actual feeders of pigs and poultry, as well as 
SEIZED AT THE FOREIGN ANIMALS WHARF. 5th March to 27th October, 1907.

\begin{tabular}{|c|c|c|c|c|c|c|c|}
\hline \multicolumn{4}{|c|}{ ARticles. } & Tons. & Owt. & Qrs. & Lbs. \\
\hline \multicolumn{4}{|c|}{ Beef (carcases and parts) } & 2 & 10 & 3 & 9 \\
\hline \multicolumn{4}{|c|}{ Calves (immature) 225} & 2 & 14 & 2 & 15 \\
\hline 302 Livers & $\ldots$ & .. & $\ldots$ & 1 & 7 & 1 & 8 \\
\hline 104 Lungs & ... & $\cdots$ & ... & - & 7 & 1 & 20 \\
\hline 21 Bellies & $\ldots$ & $\ldots$ & $\ldots$ & - & 7 & 1 & 25 \\
\hline 44 Udders & $\ldots$ & $\ldots$ & $\ldots$ & - & 3 & 3 & 20 \\
\hline 34 Hearts & $\ldots$ & $\ldots$ & $\ldots$ & - & 1 & 2 & 1 \\
\hline 24 Heads & $\therefore$ & $\cdots$ & ... & $\cdots$ & 3 & 3 & 0 \\
\hline 27 Esophag & & $\ldots$ & $\ldots$ & - & - & 1 & 22 \\
\hline 33 Intestine & & $\cdots$ & ... & -. & 2 & 3 & 22 \\
\hline 24 Reeds & ... & $\ldots$ & ... & - & - & 3 & 12 \\
\hline 20 Spleens & $\ldots$ & $\ldots$ & - & 一 & - & 2 & 4 \\
\hline 1 Paunch & ... & $\cdots$ & $\ldots$ & -- & - & 1 & 2 \\
\hline 2 Mesenter & ies & $\cdots$ & ... & - & 1 & 0 & 0 \\
\hline 13 Kidneys & $\ldots$ & $\therefore$ & $\ldots$ & - & - & 1 & 9 \\
\hline 34 Feet & $\ldots$ & $\ldots$ & $\ldots$ & - & $\cdots$ & 3 & 18 \\
\hline 12 Skirts & $\ldots$ & $\ldots$ & $\ldots$ & - & - & - & 26 \\
\hline 15 Tongues & $\ldots$ & $\ldots$ & $\ldots$ & - & - & 3 & 1 \\
\hline 5 Tails & $\ldots$ & $\ldots$ & $\ldots$ & - & - & - & 15 \\
\hline 5 Uteris & $\cdots$ & ... & $\ldots$ & 一 & - & - & 10 \\
\hline 1 Recturn & $\ldots$ & $\ldots$ & ... & - & - & - & 4 \\
\hline 1 Omentum & & $\ldots$ & $\cdots$ & - & - & - & 4 \\
\hline 1 Skull & & $\ldots$ & $\ldots$ & - & - & - & 5 \\
\hline \multirow[t]{3}{*}{ Sweetbreads. } & .... & $\ldots$ & $\ldots$ & - & - & - & 10 \\
\hline & & & Total & 8 & $\tilde{0}$ & 2 & 10 \\
\hline & & Gros & Total & 197 & 10 & 1 & 20 \\
\hline
\end{tabular}

manufacturers of poultry and animal foods. I naturally prefer to prove the assurances from actual visits by my own inspectors, and therefore do my best to concentrate the trade in damaged grain within the Manchester area; but where the stuff has been sold outside this, I have been able to get satisfactory information by communicating with the local medical officers of health.

The following results of bacteriological examinations of three samples of damaged grain will demcnstrate the importance of obtaining exact knowledge concerning ultimate destination :-

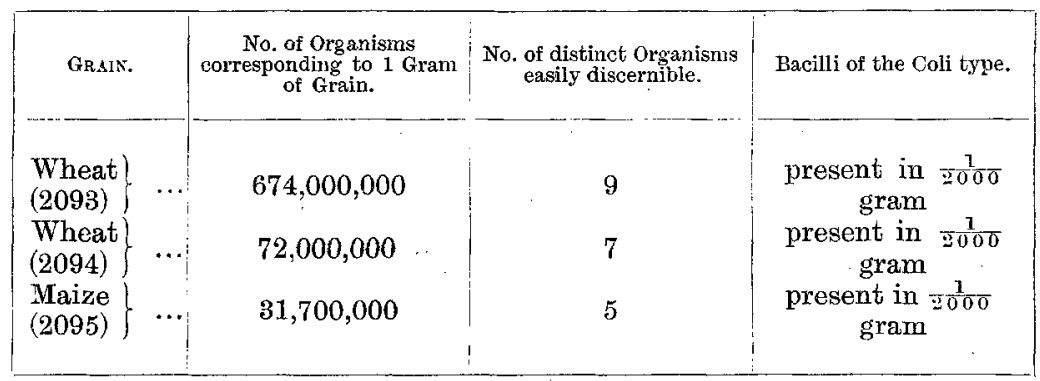


I do not for a moment contend that this class of grain is fitted for the food of dumb animals, but if such a destination is proved to me, I can, of course, do nothing to prevent it going.

Large quantities of fresh fruits are imported into Manchester from abroad; and my experience of this trade has, so far, been highly satisfactory. Manchester is now ahead of any other port in so much as concerns the importation of bananas. These are brought over under a constant even temperature, and are not likely to go wrong in transit, the damage mostly occurring through handling. The system of bounties to principal officers, initiated by the shipowners, is no doubt responsible, in a large measure, for these results. The importers are so jealous of their reputation that they themselves attend, in a most efficient manner, to the proper separating of all doubtful fruit, which is then carried away in railway waggons, and suitably disposed of to my satisfaction.

Oranges, melons, lemons, onions, apples, pears, grapes, etc., are consigned to fruit brokers in Manchester, and sold in the city by sample auction. These are sold as catalogued under their particular description as to quality, and, to have this catalogue correct, large gangs of men are employed by the brokers to sort and classify the fruit immediately a vessel begins to discharge cargo on to the quays.

My experience has been that these classifications are very correct, and that it is mainly the lower qualities which require particular attention. I found the brokers quite willing to make a working arrangement with me as regards my own inspector's examinations; and they have issued instructions to their foremen to draw attention to any parcels of a doubtful character. We have mutually agreed as to the conditions which constitute unsound fruit, and anything coming within our definition is at once surrendered. I have not had the slightest trouble with these firms during my eight months' working with the new order.

Canned goods are mainly imported direct from abroad, but a considerable, though much less amount, is brought into the port by coasters. Those coming from abroad are, with very few exceptions indeed, recently packed, and mostly turn out very satisfactory. There is the usual small percentage of blown and perforated tins, but rarely anything beyond this. There is one feature, however, which deserves your attention, and that is in connection with the "spitting " of certain percentages of these tins by the Customs officers. I have made a practice of insisting that all "spitted" tins should be at once taken possession of by wharfingers in charge, and if not satisfactorily sold for immediate consumption within twenty-four hours, they are handed over to the authority for destruction. 
The canned goods brought by coasting steamers, however, give my inspectors a great deal more trouble than those from foreign. London boats being particularly prolific in providing them with this class of material for their attention. My experience of this kind of canned goods is that it consists mainly of old packed tins. I have had a considerable quantity of apricot pulp and tomato puree to deal with from this source. I have found the tins of poor construction, with their interiors amply provided with solder for the acid contents to dissolve, and, on analysis, have found a fair amount of metallic contamination in all cases. Blown; burst, and leaky tins are quite common; and a recent consignment of tomato puree contained a very large percentage of disgracefully "faked" tins. From the battered-in appearance of these last tins it was quite evident that they had at one time been blown, and this condition, combined with the obvious evidence of resoldering, with both perforation and sweating of the seams to let out the gas, gave the best of evidence of "faking." I am quite convinced that old material of this class packed in badly-constructed tins, cannot help but be contaminated with lead and tin, and is quite unfitted for human consumption. I have seen fruit pulp, packed in Tasmania, turn out perfectly good after being several years in this country, the seams of the tins being double-lapped, and the ends fitted outside instead of inside, this meaning that no solder gets inside; and, as a general security, the interiors are coated with an impermeable varnish. It is needless to say that none of the precautions are adopted in respect to the tins of apricot pulp, ete., referred to. I hold strongly to the view that there should be either some insistence on better packing of fruit pulp, or, as an alternative, the date of packing should be stamped on each tin.

With respect to American canned meats, it is well known that large quantities, packed under conditions existing anterior to the stringent Act of Congress of June, 1906, are in store in this country. Two factors appear to have influenced the bringing into circulation of quantities of these goods, one of which is the higher price of fresh meat in America diminishing the extent of packing, and the other is the alteration in the Army and Navy Regulations with respect to the size of tins of meat admissible for service purposes. As regards the latter, old stocks of the larger-sized tins have been returned to the packers' agents in exchange for the 1-lb. and 2-1b. sizes, and these have quite naturally been put upon the market. I found a considerable percentage of "slack" tins among old consignments of compressed beef, and on opening have found accumulations of gas, presence of moulds, and metallic deposits. The metallic deposits have been 
found beneath the circular disc at one end, and unprotected perforations made in these subsequent to the first sterilization, all being unprotected by second discs placed inside the tin. I have also found a sloppy condition of the contents of a number of tins of uncompressed roast and boiled beef, such being easily ascertained on shaking. Bacteriological examination showed the meat to be perfectly sterile; but a chemical examination showed variable but very appreciable amounts of contamination with lead and tin. As the whole consignment of meat was packed and brought over under the same series of conditions, the fact of this state existing in a certain number of tins only must show that it owed its origin to some cause not common to the whole consignment. The contamination with lead and tin is the only reasonable explanation I can find for this condition, and I believe my conclusion to be fully supported by the previous experiments made by Dr. Buchanan and Dr. Schryver on the liquefaction of meat essences. The bringing of these inferior foods by coasting steamers provides a cheap means of transit, but the obvious result of our careful supervision in the Port of Manchester must mean diverting this class of traffic to the railway goods stations. This local traffic is certainly of very great importance, and any regulations made to insure supervision at the port of entry will be quite nullified if similar supervision is not insured at railway stations.

We have had two large cargoes of frozen mutton, and during the whole time of discharge I had both inspectors examining. The inspections were quite systematic, and both consignments were found to be in excellent condition.

As regards disposal of condemned food, the different local authorities in whose area such has been seized destroy the same on our behalf, and charge us out-of-pocket expenses. We have also had certain carcases and parts destroyed, under supervision, by a contractor.

A pleasing feature in our work has been the attitude of the Ship Canal Co. Although this body opposed our Bill in Parliament, they have been satisfied to allow such opposition to finish with the fight before the Committee of the House of Commons, and have since rendered us every reasonable assistance in the administration of our powers.

I have not, however, been quite so satisfied in our relations with the Customs officers. I had thought it would not be difficult for my inspectors to follow these officers in their examinations, but experience has taught me that if imported food-stuffs are to be systematically and efficiently examined, we must act quite independently of this department. Seventy-two hours is the limit for imported merchandise to lie on the quays, and I find it so common for Customs officials 
to take up such an amount of this before their inspections are completed, that the goods have vanished before we can get a look in. Although I have no desire to supplant this useful body of men from their position of paramount importance in dealings with all imports, I am of opinion that the work of food inspection is of such a nature, and of so much value to the public welfare, that no hindrance of any kind should be placed in its way. Food inspection is responsible work, and carried out by responsible officials, and unless allowed to proceed at times most suitable to those executing the work, and with a sufficient margin to insure a proper completion, the whole machinery is thrown out of gear. We must either be allowed to do this duty at our own convenience, or the removal of food stuffs must be prohibited until a clearance is given by the food inspector. The matter certainly requires attention.

I also think it worth while pointing out that the only procedure sanctioned by the Public Health Acts, to enable us to deal with a quantity of food, is to seize the whole of the consignment. It is only the unsound, however, that we require, and this is probably quite the smaller part, but to get at it the whole must be sorted. If we "seize" we should in strict law "carry away," but this would be unworkable, if not unwarrantable, in the majority of cases. After a preliminary examination, if an inspector is of opinion that a more complete inspection and sorting is required, he should be able to serve a notice of detention to enable this to be carried out. After sorting, he should then seize the unsound articles and carry them away to be dealt with according to law. When a seizure notice is served on a consignee, he cannot be supposed to know that this is simply a matter of form, intended only to secure detention for the purpose of a complete examination and sorting. To "seize" his goods is to give them a bad character, and he promptly throws them back on the consignor's hands. A simple detention notice would not prove to be so alarming, and would serve the purposes of an examining authority admirably.

Three persons suffering from Typhoid Fever came into the city in illhealth; in one instance, the patient was a milk deliverer, and had been taking round milk up to five days of the nature of the disease being recognised. A list of the streets in which he sold milk was obtained, and the medical officers of the respective boroughs were duly warned. A month has elapsed and no further cases have been notified. The man who had been employed in a similar capacity outside London up to a few weeks of being notified, is said to be suffering from consumption also.--From Report of Dr. F. J. Allan, M.O.H., City of Westminster, Dec., 1907. 